\title{
LEGAL ANALYSIS AND THE "DE FACTO" DOCTRINE
}

\section{By Alexander Hamilton Frey $\dagger$}

A general incorporation statute in each state sets forth a procedure whereby qualified persons may bring about the formation of a business corporation (or corporation for profit). Although in many states there is no explicit statutory enumeration of the legal consequences of compliance with the terms of such a general incorporation statute, it is generally understood that one of these consequences is that those who become members (shareholders) of the corporation are not personally unlimitedly liable for its obligations.

This freedom from personal liability is not an inevitable incident of incorporation. For example, until 1929 shareholders in California corporations ${ }^{1}$ were unlimitedly subject to assessment to meet unpaid debts of their corporations; today New York imposes personal liability on shareholders for unpaid wages of their corporation's employees; ${ }^{2}$ where the equities of a situation warrant it, a court may "pierce the corporate veil" and hold the shareholder or shareholders individually liable for an obligation of an association formed in complete and literal compliance with the provisions of a general incorporation statute; ${ }^{3}$ and where the members of a partnership incorporate their joint enterprise, they may be personally responsible for goods purchased by the corporation from those with whom the partnership had previously dealt who had not been notified of its incorporation. ${ }^{4}$

† A.B., 1919, Yale University; M.A., 1920, Columbia University; LL.B., 1921, J.S.D., 1925, Yale University; Ferdinand Wakeman Hubbell Professor of Law, University of Pennsylvania Law School. Author of CASES AND Materials oN Corporations and PARTNERships (1951), frequent contributor to legal periodicals.

1. The California Code, as amended 1873-74, read as follows: "\$331. The directors of any corporation formed or existing under the laws of this state, after onefourth of its capital has been subscribed, may, for the purpose of paying expenses, conducting business, or paying debts, levy and collect assessments upon the subscribed capital stock thereof, in the manner and form and to the extent provided herein." CAL. Crv. CODE AMEND. 206 (1874). In 1929 this section was amended to read as follows: "\$331(1) Shares are not assessable except as provided in this article. If the articles expressly confer such authority, and subject to any limitations therein contained the directors of any corporation may in their discretion, levy and collect assessments upon all shares of any or all classes made subject to assessment by' the articles. This authority is additional to that of making calls for the unpaid subscription price of shares." CAI. STATS. 1929, c. 711, \$17.

2. N.Y. Stock CoRp. LaW $\S 71$.

3. See Wormser, Disregard of the Corporate Fiction and Allied Corporate Problenss (1927), and Latry, Subsidiaries and Afriliated Corporations (1936).

4. See Mulkey v. Anglin, 166 Okla. 8, 25 P.2d 778 (1933). 
Conversely, limited liability may be achieved by members of business groups without incorporating. For example, the members of associations such as the Pennsylvania "partnership association" " or "registered partnership" " are accorded by statute freedom from personal liability for obligations of their associations ; ${ }^{7}$ one's liability for a particular obligation may be limited by contract to a designated portion of his assets $;^{8}$ and even a defective attempt to comply with the terms of a general incorporation statute may nevertheless insulate the members of the resulting association from personal liability for obligations of the association. The object of this paper is not to explore all the areas from which limited liability may or may not emerge, but rather to examine with particularity this matter of liability with reference to certain typical defects or irregularities in the process of attempting to form a corporation under a general incorporation statute.

The purpose of this preliminary reference to incorporation without limited liability, and to limited liability without incorporation, is to dispose of the semantic dogmatism that limited liability is an attribute of a corporation and only of a corporation. When the issue is in doubt, one cannot logically determine that the members of an association are or are not personally liable for their association's debts by first arriving at a conclusion that the association should or should not be labelled a corporation; similarly, if the appellation of an association is in issue for some purpose other than limited liabiilty, one cannot logically maintain that the association is for all purposes a corporation merely because the members of the association enjoy limited liability with reference to the debts of the association. ${ }^{9}$ During the course of

5. PA. Stat. ANn. tit. 59, $\$ \$ 341-461$ (Purdon 1930). See especially $\S 381$.

6. PA. Stat. Ann. tit. 59, $\$ \S 241-321$ (Purdon 1930). See especially $\$ 261$. (1933).

7. See Note, Business Associations in Pennsylvania, 82 U. of PA. L. Rev. 151

8. Such limited liability as is incident to a business (or "Massachusetts") trust is essentially contractual. See Comment, Massachusetts Trusts, 37 YALE L.J. 1103 (1928).

9. Consider two rules of law: (1) the shareholders in a corporation are not personally liable for its obligations, and (2) a valid conveyance of real property can be made to a corporation in its corporate name. Assume that, in an effort to form corporation $\mathrm{X}$, articles of incorporation are recorded in the office of the appropriate secretary of state but not in the county where the association's principal place of business is located; assume further that this omission is a violation of an applicable statute. Thereafter, for the purpose of interpreting and applying rule (1), the association is held to be a "corporation," and the shareholders not personally liable for its obligations. If, subsequently, a case arises involving the interpretation and application of rule (2), the previous interpretation of rule (1) is not controlling, and for the purpose of construing rule (2), the association in question may be held, without doing violence to the principal of stare decisis, not to be a corporation and not capable of receiving an effective conveyance in its association name. The problems are independent, and in each case the decision will turn, not upon the previous designation of the association for some other purpose, but upon the particular court's conclusions as to the policies to be subserved by the respective rules. If the defect is a failure to pay in the required minimum of capital, this omission might be regarded as a strong 
this paper it will appear that some defects in the effort to incorporate result, under certain circumstances, in the shareholders being personally liable for obligations of the association, and other defects do not; whatever reason there may be for these divergencies, it is not to be found by proclaiming that in the one case the would-be incorporators formed an unintended partnership, and in the other a corporation.

If a business association purports to be incorporated under a given general incorporation statute but literal and complete compliance with the provisions of that statute has not occurred, what are the legal incidents of the resulting association? Is the liability of the members of the association for its obligations limited? Can an action be maintained on behalf of the association in the association name? Can an action be brought against the association without naming and serving the members individually as parties defendant? Are the interests of a member of the association transferable without the consent of the other members?. The answers to some of these questions may be in the affirmative and to others in the negative, depending upon the nature of the defect in the attempt to incorporate and other relevant circumstances. ${ }^{10}$ The association in question may be hybrid: it may have some attributes which are normally associated with the term "corporation" and others normally associated with the term "partnership." Where the facts giving rise to the association are admittedly abnormal or irregular, it is only after its major incidents have been determined one by one that an intelligent conclusion can be arrived at as to whether or not it is accurate, i.e., feasible or convenient, to refer to the association as a corporation, partnership, business trust, joint stock company, etc. To conclude, for example, that the members of such an association are unlimitedly liable because their association is a partnership is to indulge in circuitous reasoning, i.e., they are liable because they are liable. Where the underlying facts are abnormal, there is no way of determining authoritatively that the association "is a partnership" or "is a corporation," because no single case will have required a court to determine that the abnormal association has all of the legal attributes of a normally formed corporation or partnership.

There are two propositions which very generally are stated by courts and text writers with respect to the consequences of defective attempts to incorporate. First, if there has been substantial compliance with the provisions of a statute authorizing the formation of a corpora-

reason for holding the associates personally liable for obligations of the association, but does it provide equal justification for denying to creditors of the association the power to sue it in its association name, if they so choose, rather than by naming and serving all of the individual associates as parties defendant?

10. See note 9 supra. 
tion having the objects and structure of the one in question (that is, if the non-compliance is slight), a "de jure" corporation results, namely, an association which the courts will recognize as a corporation for all purposes and as to all parties, including the state of incorporation. ${ }^{11}$ Secondly, if (a) there is a law in the state of alleged incorporation under which such a corporation might be formed, and (b) there has been a colorable or apparent attempt (c) in good faith to incorporate under such law, and (d) some corporate "user" has occurred, i.e., some exercise of corporate powers, a "de facto" corporation results, namely, an association which the courts will recognize as a corporation for all purposes and as to all parties except the state of incorporation; by quo warranto proceedings the state may terminate the life as a corporation. of such an association, but no one else may challenge its corporate existence. $^{12}$

Two major difficulties with this analysis present themselves. In the first place, these propositions fail to reveal (a) what acts of incomplete compliance with the incorporation statutes are sufficient to constitute "substantial" compliance, and (b) what acts, insufficient for "substantial" compliance, are nevertheless enough for a "colorable" or "apparent" attempt to comply. Secondly, these propositions do not give even a verbal indication of the legal consequences of purported incorporation where the acts done are less than a "colorable" attempt to comply with the incorporation statute, or where one or more of the other three elements of a so-called "de facto" corporation is lacking. This traditional approach blandly assumes that merely by considering the character or extensiveness of the defect in the effort to incorporate, it is possible to predict all of the legal attributes which courts will ascribe to the associates, e.g., all of the attributes of shareholders ("de jure" corporation), or all of the attributes of shareholders except vulnerabiilty to attack by the state ("de facto" corporation). But I suspect that it is not possible to foretell with assurance even the presence or absence of a single attribute, such as limited liability of the associates, merely by dwelling upon the factual content of a particular defect in the attempt to incorporate and the policies underlying the unfulfilled statutory requirement.

To test this hypothesis I have sought to gather and analyze all the reported American cases in which a "corporate" creditor ${ }^{13}$ is seeking

11. See Ballantine, Corporations 76 (rev. ed. 1946) and Stevens, CorporaTIONS 112 (2d ed. 1949).

12. See Ballantine, op. cit. supra note 11, $77 \mathrm{ff}$. and Stevens, op. cit. supra note $11,139 \mathrm{ff}$.

13. The expression "corporate" creditor refers to a creditor of an association resulting from a defective attempt to incorporate. 
to obtain a judgment against one or more of the associates ("shareholders") personally, because of a non-compliance with some provision of a general incorporation act concerning the prescribed procedure for bringing a corporation into existence, and in which the outcome of the case is not controlled by an explicit statute. ${ }^{14}$

The typical general incorporation act provides that there shall be drafted an instrument, most frequently referred to as "articles of incorporation," containing as a minimum certain stipulated items of information, executed by a sufficient number of qualified incorporators, and recorded in the office of the secretary of state and also with the clerk of the county in which the principal office or place of business is to be located. ${ }^{15}$ The payment of designated fees is usually required in conjunction with the recordation of the articles. In addition to the foregoing formalities, the statutes of many states further provide that "corporate existence" shall not begin, or the privilege of doing business in corporate form shall not accrue, until a stipulated minimum of paid-in capital shall have been obtained. ${ }^{16}$ The omission of any one of these steps in the incorporating process may lead to the contention that the members of the association are personally liable (as partners would be) for its obligations, on the theory that the legislature offered the privilege of limited liability only to those who would do the acts required to bring a corporation into existence, that this offer was not accepted because the required acts were not done, and that hence the associates are not immune from the normal business consequence of personal liability. ${ }^{17}$ Such claims have been occasioned more frequently by some defects in the incorporating process than by others. I shall examine herein only those cases which are concerned with the more provocative defects.

Preliminary research suggested two factors that might be of particular significance with reference to the liability of the associates for obligations of the defectively "incorporated" association: (1) whether or not the defendant associates were active in the management of the association, and (2) whether or not the plaintiff dealt with the association on a corporate basis. ${ }^{18}$ Although the relevant judicial opinion sel-

14. In some jurisdictions there are statutes which expressly impose personal liability on the shareholders. See, e.g., IowA CODE $\$ 491.22$ (1950): "A failure to substantially comply with the foregoing requirements in relation to organization and publicity shall render the individual property of the stockholders liable for the corporate debts. ..."

15. See, e.g., DeL. CoRp. LAW ANN. \$6 (1951).

16. See, e.g., Pa. Stat. ANN. tit. 15, \$2852-208 (Purdon, 1950).

17. See, e.g., Dodd, Partnership Liability of Stockholders in Defective Corporations, 40 HARv. L. REv. 521 (1927), and Magruder's reply thereto in 40 HARV. L. REv. 733 (1927).

18. Throughout this article the plaintiff and the association are said to have had "dealings on a corporate basis" if the association had been represented to him as in- 
dom stress either of these factors as part of the rationale underlying the decisions, in the following analysis of the cases the presence or absence of each of these factors will be indicated in an effort to ascertain the extent to which either may constitute an unexpressed major premise. The cases will be grouped under each of the more frequent types of defect.

\section{Articles of Incorporation Not Recorded at Ali}

Every general incorporation statute requires as part of the process of incorporation some form of recordation of the articles of incorporation, almost always in the office of the secretary of state and usually also in the county in which the principal office of the association is located. One might suppose that any sincere effort to form a corporation would result in some recordation of the proposed articles of incorporation or other formative document. There have, however, been thirty-five cases of actions against the shareholders personally based on a complete absence of recordation of the articles. A typical instance is where the articles are drafted and executed in due form and turned over to an attorney for recordation, but he neglects to place the articles on any public record at least until after the obligation has been incurred upon which the "shareholders" are being personally sued. ${ }^{10}$

One might further suppose that where no public record of the purported incorporation has been made, the courts will almost uniformly hold that the associates have not gone far enough to achieve the attribute of limited liability. But in twelve of the thirty-five cases the associates are held not to be personally liable to the "corporate" creditor; and if we analyze these cases with respect to whether or not the plaintiff dealt with the association believing it to be a corporation, the results are even more surprising. In ten of the cases the dealings were not on a corporate basis, and in nine of these cases personal liability is imposed upon the defendant associates. ${ }^{20}$ In the remaining twenty-five

corporated and if, in his dealings with the association, he did not contest the accuracy of this representation; the parties are said not to have had "dealings on a corporate basis" either if the plaintiff had not dealt with the association, as in the normal tort case, or if the designation of the association is ambiguous and, in his dealings with the association, the plaintiff justifiably assumed it was unincorporated or showed no concern with its legal status.

19. See, e.g., Magnolia Shingle Co. v. J. Zimmern's Co, 3 Ala. App. 578, 58 So. 90 (1912); Tisch Auto Supply Co. v. Nelson, 222 Mich. 196, 192 N.W. 600 (1923); Baker v. Bates-St. Shirt Co., 6 F.2d 854 (1st Cir. 1925).

20. Michael Bros. Co. v. Davidson \& Coleman, 3 Ga. App. 752, 60 S.E. 362 (1908) ; Bigelow v. Gregory, 73 IIl. 197 (1874); Spencer Field \& Co. v. Cooks, 16 La. Ann. 153 (1861) ; Ferris v. Thaw, 72 Mo. 446 (1880); Smith v. Warden, 86 Mo. 382 (1885) ; Queen City Co. v. Crawford, 127 Mo. 356, 30 S.W. 163 (1895); Luck v. Alamo Printing Co., 190 S.W. 204 (Tex. Civ. App. 1916) ; Bank of De Soto v. Reed, 50 Tex. Civ. App. 102, 109 S.W. 256 (1908); Owen v. Shepard, 59 Fed. 746 (8th Cir. 1894). 
cases the dealings were on a corporate basis, and the associates are held to be personally liable in fourteen ${ }^{21}$ and not liable in eleven. ${ }^{22}$

In three of the cases where the dealings were not on a corporate basis, the defendant associates were not active in the management but are nevertheless held to personal liability, ${ }^{23}$ and in the one holding of non-liability the defendant was a managing associate. ${ }^{24}$ In the twentyfive cases where the dealings were on a corporate basis, inactive associates are held liable ten times ${ }^{25}$ and not liable nine times; ${ }^{26}$ managing associates are held liable four times ${ }^{27}$ and not liable two times. ${ }^{28}$

From the foregoing analysis of the cases it would appear that if the shareholders in a defectively incorporated association are charged with personal liability because of a complete failure to record the proposed articles of association in any public office, the judgment is extremely likely to go against them if the plaintiff did not deal with them as an association with limited liability; but they have an almost even chance of prevailing if the plaintiff, in his dealings with them, was aware that they purported to be incorporated with the normal incidents of a corporation including limited liability. Whether or not the defendants were active in the management of the association at the time the obligation arose seems to be of negligible importance.

21. Harris v. Ashdown Ass'n, 171 Ark. 399, 284 S.W. 755 (1926); Bailey v. Sutton, 208 Ark. 184, 185 S.W.2d 276 (1945) ; Pettis v. Atkins, 60 I11. 454 (1871); Coleman v. Coleman, 78 Ind. 344 (1881) ; McLennan v. Hopkins, 2 Kan. App. 260, 41 Pac. 1061 (1895) ; Spencer Field \& Co. v. Cooks, 16 La. Ann. 153 (1861); Lind v. Senton, 10 La. App. 633, 120 So. 535 (1929) ; Campbell v. Rukamp, 260 Mich. 43, 244 N.W. 222 (1932) ; Richardson v. Pitts, 71 Mo. 128 (1879); Weir Co. v. Bodwell, 73 Mo. App. 389 (1898); Abbott v. Omaha Co., 4 Neb. 416 (1876) ; Federal Advertising Corp. v. Hundertmark, 109 N.J.L. 12, 160 Atl. 40 (1932) ; Tuccillo v. Pittelli, 127 N.Y. Supp. 314 (1911); Harrill v. Davis, 168 Fed. 187 (8th Cir. 1909).

22. Magnolia Shingle Co. v. J. Zimmern's Co., 3 Ala. App. 578, 58 S. 90 (1912); Tarbell v. Page, 24 I11. 46 (1860) ; Heald v. Owen, 79 Iowa 23, 44 N.W. 210 (1890); John Lucas \& Co. v. Bernhardt's.Estate, 156 La. 207, 100 So. 399 (1924) ; Lockwood v. Wynkoop, 178 Mich. 388, 144 N.W. 846 (1914) ; Tisch Auto Supply Co. v. Nelson, 222 Mich. 196, 192 N.W. 600 (1923) ; Berlin Bank v. Nelson, 231 Mich. 463, 204 N.W' 92 (1925); A.W. Mendenhall Co. v. Booher, 226 Mo. App. 945, 48 S.W.2d 120 (1932) ; Mason v. Stephens, 16 S.D. 320, 92 N.W. 424 (1902) ; Baker v. Bates-Street Shirt Co., 6 F.2d 854 (1st Cir. 1925) ; Whitney v. Wyman, 101 U.S. 392 (1879).

23. Spencer Field \& Co. v. Cooks, Ferris v. Thaw, and Smith v. Warden, all cited in note 20 sucpra.

24. Frawley v Tenafly Transportation Co., 95 N.J.L. 405, 113 Ati. 242 (1921).

25. Harris v. Ashdown Ass'n, Pettis v. Atkins, Coleman v. Coleman, McLennan v. Hopkins, Spencer Field \& Co. v. Cooks, Lind v. Senton, Campbell v. Rukamp, Richardson v. Pitts, Weir Co. v. Bodwell, Abbott v. Omaha Co., all cited in note 21 sinpra.

26. Magnolia Shingle Co. v. J. Zimmern's Co., Tarbell v. Page, Heald v. Owen, Tisch Auto Supply Co. v. Nelson, Berlin Bankov. Nelson, A. W. Mendenhall Co. v. Booher, Mason v. Stephens, Baker v. Bates-Street Shirt Co., Whitney v. Wyman, all cited in note 22 supra.

27. Bailey v. Sutton, Federal Advertising Corp. v. Hundertmark, Tuccillo v. Pittelli, Harrill v. Davis, all cited in note 21 supra.

28. John Lucas \& Co. v. Bernhardt's Estate, Lockwood v. Wynkoop, both cited in note 22 supra. 
One might expect that the cases in which the dealings were not on a corporate basis would involve tort claims (which the plaintiffs did not elect to suffer from corporations!), but actually in eight of the ten cases the claims are for goods sold, money lent or services rendered; the plaintiffs did not know or apparently care whether the association to which credit was being extended was incorporated or not, and it is for this reason that the transactions are herein classified as not having been on a corporate basis. In most of the ten cases articles of incorporation had been drafted, but due to carelessness or negligence had not been recorded at the time the claim arose. In one case a petition for a charter had been applied for but it had not as yet been granted; ${ }^{29}$ and in the only case of dealings not on a corporate basis in which the defendants are exonerated from personal liability, ${ }^{30}$ the articles had been executed two days before the tort, were en route for recordation at the time of the accident, were recorded the next day by the county clerk, and were filed in the office of the secretary of state four days later.

In these cases where dealings were not on a corporate basis and the defendants are held personally liable, the courts do not discuss the purpose or policy behind the statutory requirements as to recordation of articles of incorporation. In most of the cases the reason assigned for holding the defendants liable is either that they did not incorporate and hence are partners or that the failure to record the articles was such a substantial defect as to make the incorporating process invalid, and therefore the defendants did not immunize themselves from those personal liabilities which are the normal risks of engaging in business.

The judicial reasoning is very similar in the fourteen cases where the dealings were on a corporate basis and the defendants are held personally liable. In one of these cases the court states that the defendants failed to incorporate and hence are liable whether they are partners or not, ${ }^{31}$ but in most of the opinions the thought expressed is that the defendants, having failed to incorporate, are partners and liable as such. Some of the cases base the defendants' liability on the conclusion that they have failed to create a corporation, "de jure" or "de facto." 32 It is said in one of the opinions that the defect in the incorporating process causes the defendants to be liable as partners unless the contract with the plaintiff specifies that he, the obligee, will look to the association only and not to the members of the association for payment. ${ }^{33}$

29. Michael Bros. Co. v. Davidson \& Coleman, supra note 20.

30. Frawley v. Tenafly Transportation Co., supra note 24.

31. Richardson v. Pitts, supra note 21.

32. See, e.g., Harris v. Ashdown Ass'n, supra note 21.

33. Weir Co. v. Bodwell, supra note 21. 
The foregoing analysis reveals that, where personal liability is imposed upon the defendant members of the association, the general attitude of the judiciary in these cases is that complete failure to record the articles of incorporation nullifies whatever other steps toward incorporation may have occurred and leaves the associates with the unlimited liability of members of a partnership, albeit an unintended one. Before the validity or invalidity of this reasoning is discussed, the twelve cases in which the defendant associates are held not to be personally liable will be examined. Only one of these cases involves a plaintiff who had not dealt with the association on a corporate basis. ${ }^{34}$ At the time of the accident upon which this plaintiff's claim is based the articles of incorporation were en route for recordation, and were recorded the next day. The plaintiff sued the corporation and the three incorporators individually. The corporation maintained that the individual defendants were liable as partners, and that it was not liable, because the process of incorporation had not been completed at the time the accident occurred. The court gave judgment for the plaintiff against the corporation only. This exoneration of the incorporators was apparently on the ground that, prior to the accident, they had proceeded in good faith far enough along a path which very shortly thereafter led to complete incorporation: they had also purchased property and secured licenses in the corporate name, and had paid their employees in envelopes bearing the name of the corporation.

Some of the eleven cases of non-liability in which the dealings were on a corporate basis present special facts. For example, in one case the plaintiffs were directors of the unrecorded "corporation" who had lent money to the enterprise and who sought to recover against the shareholders as partners. ${ }^{35}$ The court gave judgment for the defendants on two grounds: first, that the contractual relationship between them and the plaintiff was that of shareholders in a corporation; and secondly, that the loan in question had exceeded the debt limit set forth in the articles, and hence was unauthorized. Despite this latter factor, this case does recognize that limited liability may be achieved by contract even if an effort to incorporate is abortive. In another case the articles had been submitted to the secretary of state, but had been returned by his office for certain corrections. ${ }^{36}$ On the same day the plaintiff bank discounted a note of the association, admittedly presuming and supposing it to be a corporation. Here, too, the articles were duly recorded not long after the transaction in question. The court held that the

34. Frawley v. Tenafly Transportation Co., supra note 24.

35. Heald v. Owen, supra note 22.

36. Lockwood v. Wynkoop, supra note 22 . 
plaintiff, having dealt with the association as a corporation, was estopped from denying its corporate existence for the purpose of charging the incorporators as partners. But most of these cases are not particularly different on their facts from the cases previously discussed where an opposite result was reached. The significant distinction is in the attitude of the court. In these cases in which the associates are accorded freedom from personal liability, either the court proclaims that their bona fide effort to incorporate produced a "de facto" corporation ${ }^{37}$ despite the complete failure to record the proposed articles of incorporation at the time the obligation in question arose, or the court asserts that the plaintiff, having accepted them as a corporation when the transaction took place, is estopped ${ }^{38}$ from charging the associates with personal liability.

To summarize: In the cases where the dealings were not on a corporate basis the courts are virtually unanimous in holding the associates personally liable, and, in general, the professed justification is that the defendants are partners, corporate existence not having begun because of the complete omission of recordation of the articles. In the cases where the dealings were on a corporate basis the courts are rather evenly divided with respect to imposing personal liability on the associates; the courts holding them liable employ substantially the same reasoning as is found in the cases where the dealings were not on a corporate basis; but the courts exonerating them from personal liability have quite a different philosophy. They minimize the importance of recording the articles, and concede that despite this defect a "de facto" corporation may result if the association had other indicia of incorporation; or, while stating that a "de facto" corporation did not result, they assert that the plaintiff is "estopped" by his dealings from denying the defendants' corporate existence. Although this "estoppel" argument is rather far-fetched since the plaintiffs did not misrepresent to the defendants that the defendants were incorporated, nevertheless it is important as an oblique recognition that limited liabiilty may emerge from a consensual transaction despite significant noncompliance with the provisions of a general incorporation statute. To further test the reaches of this "estoppel" doctrine, the next group of cases considered will be those in which no attempt to incorporate had been made by the associates who purported to be a corporation.

37. See, e.g., Coleman v. Coleman, Spencer Field \& Co. v. Cooks, Lind v. Senton and Richardson v. Pitts, all cited in note 21 supra.

38. See, e.g., Harris v. Ashdown Ass'n, Bailey v. Sutton, McLennan v. Hopkins, and Abbott v. Omaha Co., all cited in note 21 supra. 


\section{No Attempt to InCorporate}

In one sense, these cases ought not to be included in this paper since they present not a defect in incorporation but an absence of incorporation. But they provide excellent material for examining the readiness of courts to uphold limited liability without incorporation, either on an "estoppel" or a "contract" doctrine. If A, B and C, having taken no steps to incorporate, nevertheless represent themselves to the world as the Acme Hat Corporation, and if $\mathrm{P}$ enters into a transaction with this business enterprise, believing from its designation that it is in fact incorporated, should $\mathrm{P}$ be able to hold $\mathrm{A}, \mathrm{B}$ and $\mathrm{C}$ personally liable for an obligation emerging from this transaction? Is $P$ "estopped"? Has $\mathrm{P}$ contracted to limit his claim to the property which $\mathrm{A}, \mathrm{B}$ and $\mathrm{C}$ have permanently dedicated to this business enterprise and not to have recourse to their non-business assets? If $A, B$ and $C$ have merely contributed to the capital of the enterprise, but are not active in the management and did not participate in the transaction with $P$, is his case against them stronger or weaker?

- The cases analyzed in the preceding section were all cases in which some portion of the prescribed statutory procedure for incorporation had occurred, usually at least the drafting of proposed articles of incorporation, but the recordation requirements had been completely omitted. In the cases dealt with in the present section no articles of incorporation were drawn up, and no steps taken in partial compliance with the provisions of a general incorporation statute. The corporate aspect of the business enterprise in these cases results either from a bald mislabeling of the association as a corporation, or from a clumsy pretense of incorporation through some device such as the purchase of the "franchise" of a defunct corporation. ${ }^{39}$ From the respective cases considered as a group, it is apparent that the courts regard the absence of any attempt to incorporate as much more significant, with respect to limited liability, than total non-compliance with the requirements as to recordation of the articles. Seventeen cases ${ }^{40}$ have been collected in which

39. See, e.g., Forbes v. Whittemore, 62 Ark. 229, 35 S.W. 223 (1896), and Booth v. Wonderly, 36 N.J.L. 250 (1873).

40. Forbes v. Whittemore, 62 Ark. 229, 35 S.W. 223 (1896); Doyle-Kidd Dry Goods Co. v. A. W. Kennedy \& Co., 154 Ark. 573, 243 S.W. 66 (1922) ; Meinhard, Schaul \& Co. v. Bedingfield Co., 4 Ga. App. 176, 61 S.E. 34 (1908) ; McRee v. Quitman Oil Co., 16 Ga. App. 12, 84 S.E. 487 (1915); Hagan v. Asa G. Candler, Inc., 189 Ga. 250, 5 S.E.2d 739 (1939); Liebold v. Green, 69 I11. App. 527 (1897) ; McClaren v. Dawes Electric Sign Co., 86 Ind. App. 196, 156 N.E. 584 (1927) ; Amer. Mutuai Liability Ins. Co. v. Condon, 280 Mass. 517, 183 N.E. 106 (1932); Hughes Co. v. Farmers Union Produce Co., 110 Neb. 736, 194 N.W. 872 (1923); Booth v. Wonderly, 36 N.J.L. 250 (1873); Imperial Shale Co. v. Jewett, 169 N.Y. 143, 62 N.E. 167 (1901); Fuller v. Rowe, 57 N.Y. 23 (1874); Puro Filter Corp. v. Trembley, 266 App. Div. 750, 53 N.Y.S.2d 472 (1943); Perrine v. Levin, 123 N.Y. Supp. 1007 (1910); Seacord v: Pendleton, 62 N.Y. (55 Hun. 579, 9 N.Y. Supp. 46 (1890); Mapel v. Long-Bell Lumber Co., 103 Okla. 249, 229 Pac. 793 (1924) ; Hess v. Werts, 4 S. \& R. 356 ( $\mathrm{Pa} .1818$ ). 
claims of personal liability are asserted against members of associations which purported to be corporations although no attempt to incorporate had occurred, and in fifteen ${ }^{41}$ of these cases the plaintiffs prevail.

In four ${ }^{42}$ of the seventeen cases the dealings were not on a corporate basis, and in each instance the defendants are held personally liable, although in two ${ }^{43}$ of these cases they were not active in the management of the enterprise. This factor of degree of participation in the transaction out of which the suit arises seems to be a trifle more significant here than in the preceding section. Where the dealings were on a corporate basis, managing associates were defendants in seven ${ }^{44}$ cases, and inactive associates in six; ${ }^{45}$ the managing associates are found to be personally liable in all seven cases, whereas in only four ${ }^{40}$ of the other six cases are inactive associates so held.

In a number of the cases with which this section is concerned, there is no clear-cut indication as to whether the plaintiff dealt with the defendants on a corporate basis, and it must be admitted that the classification of some of these cases is unavoidably speculative. But there is nothing speculative about the attitude of the courts. When confronted with no attempt to incorporate the judicial mind summarily rejects the idea of "de facto" corporate existence; ${ }^{47}$ and even where the plaintiff clearly thought he was dealing with a corporation, the courts show little awareness of the "estoppel" doctrine ${ }^{48}$ which loomed large in the preceding section. The reasoning of these courts seems to start from the premise that when no attempt to incorporate can be found, the members of the association are personally liable for its obligations, and the fact that the plaintiff was duped into believing he was dealing with a corporation will not be regarded as proof that he contracted to limit his claim to the assets of the association. In deciding in favor of the

41. The two cases in which plaintiff did not prevail are Fuller v. Rowe and Seacord v. Pendleton, both cited in note 40 supra

42. Meinhard, Schaul \& Co. v. Bedingfield Co., Liebold v. Green, Hughes Co. v. Farmers Union Produce Co., and Mapel v. Long-Bell Lumber Co., all cited in note 40 supra.

43. Liebold v. Green and Hughes v. Farmers Union Produce Co., both cited in note 40 supra.

44. Forbes v. Whittemore, McRee v. Quitman Oil Co., Hagan v. Asa G. Candler, Inc., McClaren v. Dawes Electric Sign Co., Amer. Mutual Liability Ins. Co. v. Condon, Booth v. Wonderly, and Puro Filter Corp. v. Trembley, all cited in note 40 supra.

45. Doyle-Kidd Dry Goods Co. v. A. W. Kennedy \& Co., Imperial Shale Co. v. Jewett, Fuller v. Rowe, Perrine v. Levin, Seacord v. Pendleton, and Hess v. Werts, all cited in note 40 supra.

46. Doyle-Kidd Dry Goods Co. v. A. W. Kennedy \& Co., Imperial Shale Co. v. Jewett, Perrine v. Levin, and Hess v. Werts, all cited in note 40 supra.

47. See, e.g., Doyle-Kidd Dry Goods Co. v. A. W. Kennedy \& Co., and Hughes Co. v. Farmers Union Produce Co., both cited in note 40 supra.

48. See, e.g., McClaren v. Dawes Electric Sign Co., and Puro Filter Corp. v. Trembley, both cited in note 40 supra. 
plaintiff, some courts specifically refer to the doctrine that an agent for a non-existent principal is personally liable. ${ }^{49}$ Since the courts are apparently ready to hold the defendants liable in any event, it is little wonder that they sometimes do not bother to reveal whether or not the dealings were on a corporate basis.

The analysis of the cases in this section substantiates the classical "de facto" doctrine to this extent: for limited liability based on purported incorporation there must be some bona fide attempt to comply with the provisions of a general incorporation statute. But from these cases one cannot deduce how much or how little compliance will suffice. A further analysis of the partial compliance cases is needed; the cases in which the articles of incorporation were recorded locally but not with the secretary of state will next be examined.

\section{Articles of Incorporation Not Recorded Wite Secretary of State But Recorded Locally}

In every state the general incorporation statute requires the proposed articles of incorporation to be recorded (or filed) with a state official, almost always the secretary of state, but occasionally a corporation commission or an equivalent body. Many states require the articles also to be recorded locally, usually in the office of the clerk of the county where the corporation's principal office is to be located, or in the office of a probate judge or similar official. If this system of dual recordation is in effect, the articles are usually required to be recorded (or filed) first in the office of the secretary of state and then with the local official, although in some states this process is reversed. The cases presented in this section are all cases in which the applicable statute required dual recording, and in which the articles were recorded locally, but not in the office of the secretary of state at the time the plaintiff's claim arose. Sixteen such cases have been discovered; ${ }^{50}$ it so happens that in all of them the dealings appear to have been on a corporate basis.

49. See Hagan v. Asa G. Candler, Booth v. Wonderly, and Puro Filter Corp. v. Trembley, all cited in note 40 supra.

50. Morse v. Burkart Mfg. Co., 154 Ark. 362, 242 S.W. 810 (1922); Wesco Supply Co. v. Smith, 134 Ark. 23, 203 S.W. 6 (1918); Garnett v. Richardson, 35 Ark. 144 (1879) ; Doty v. Patterson, 155 Ind. 60, 64, 56 N.E. 668, 669 (1900); Bond \& Braswell v. Scott Lumber Co., 128 La. 818, 55 So. 468 (1911); General Motors Acceptance Corp. v. Thomas, 33 S.W.2d 1033 (Mo. 1930); Martin v. Fewell, 79 Mo. 401 (1883) ; Hurt v. Salisbury, 55 Mo. 310 (1874) ; Farmers Bank v. Kuchs, 163 Mo. App. 606, 147 S.W. 862 (1912) ; Glenn v. Bergmann, 20 Mo. App. 343 (1886); Nebraska Bank v. Ferguson, 49 Neb. 109, 68 N.W. 370 (1896) ; Burstein v. Palermo, 104 N.J.L. 414, 140 Atl. 326 (1928); Vanneman v. Young, 52 N.J.L. 403, 20 Atl. 53 (1890); Jessup v. Carnegie, 80 N.Y. 441 (1880); Mitchell v. Jensen, 29 Utah 346, 81 Pac. 165 (1905) ; Heisen v. Churchill, 205 Fed. 368 (7th Cir. 1913). 
These cases reveal no decided trend: in nine cases ${ }^{51}$ the defendants are exonerated from personal liability, and in seven cases ${ }^{52}$ the plaintiffs prevail. It will be noted, however, that the states divide seven to three in favor of the defendants. Participation in the management of the enterprise by the defendants did not materially affect the outcome. In five of the sixteen cases the defendants were active in the management; they are held liable in two cases, ${ }^{53}$ and not liable in three. $^{54}$ In the remaining eleven cases actions against associates not active in the management are successful in five instances, ${ }^{55}$ and unsuccessful in six..68

The cases in which the courts refused to hold the associates personally liable most frequently relied upon the "de facto" doctrine as justification for this result. ${ }^{57}$ But some of the decisions in favor of the defendants were also based on the theory that plaintiff, having dealt with the association as a corporation, was estopped to deny its corporate existence, ${ }^{58}$ despite the failure to record the articles with the secretary of state.

Where an opposite result was reached, the typical reasoning was that there could be no corporate existence prior to recording the articles with the secretary of state, ${ }^{59}$ and that "therefore" the members or officers of the association were personally liable. It should be noted that in at least one of the cases ${ }^{60}$ the outcome may have been influenced by the presence of other defects in the attempt to incorporate.

The most startling fact about this group of cases is that the courts appear to give little or no consideration to the purpose behind the requirement of recordation of the articles in the office of the secretary of

51. Wesco Supply Co. v. Smith, Doty v. Patterson, Bond \& Breswell v. Scott Lumber Co., General Motors Acceptance Corp. v. Thomas, Farmers Bank v. Kuchs, Nebraska Bank v. Ferguson, Burstein v Palermo, Vanneman v. Young, Jessup v. Cárnegie, all cited in note 50 supra.

52. Morse v. Burkart Mfg. Co., Garnett v. Richardson, Martin v. Fewell, Hurt v. Salisbury, Glenn v. Bergman, Mitchell v. Jensen, Heisen v. Churchill, all cited in note 50 supra.

53. Hurt v. Salisbury, Heisen v. Churchill, both cited in note 50 supra.

54. Wesco Supply Co. v. Smith, General Motors Acceptance Corp. v. Thomas, Burstein v. Palermo, all cited in note 50 supra.

55. Morse v. Burkart Mfg. Co., Garnett v. Richardson, Martin v. Fewell, Glenn v. Bergman, Mitchell v. Jensen, all cited in note 50 supra.

56. Doty v. Patterson, Bond \& Breswell v. Scott Lumber Co., Farmers Bank v. Kuchs, Nebraska Bank v. Ferguson, Vanneman v. Young, Jessup v. Carnegie, all cited in note 50 supra.

57. See, e.g., Wesco Supply Co. v. Smith, Doty v. Patterson, Nebraska Bank v. Ferguson, Burstein v. Palermo, all cited in note 50 supra

58. See, e.g., Wesco Supply Co. v. Smith, Bond \& Breswell v. Scott Lumber Co., Nebraska Bank v. Ferguson, Vanneman v. Young, all cited in note 50 supra.

59. See, e.g., Martin v. Fewell, Hurt v Salisbury, Heisen v. Churchill, all cited in note 50 supra.

60. Mitchell v. Jensen, cited in note 50 supra. 
state. Hence, the reasoning in the opinions is strictly conceptual ("corporation" or "no corporation"), and is not concerned with the question of nexus, if any, between failure to record the articles with the secretary of state and personal liability of the members of the association. Nor do some of these courts appear to be aware that the designation of an association as "not a corporation" does not determine what it is, i.e., what attributes it does have. Describing an object as "not white" does not reveal what its color is, and it would not be logical to conclude from this description that the color of the object must be the opposite of white, i.e., black. Similarly, the members of an association which is "not a corporation" are not by logical inevitability partners. Sound policy may induce a court to decree that the attributes of an association resulting from a defective attempt to incorporate shall be adjudged in relation to the character of the defect and the legislative purposie behind the requirement.

There is very little difference between the outcome of these cases as a group and the results of the group of cases in which there had been no recordation at all and dealings were on a corporate basis. ${ }^{61}$ Apparently, when the articles have not been recorded with the secretary of state, the courts regard recordation in the local county almost as the equivalent of no recordation at all. To further test this conclusion the cases will next be examined in which the articles were recorded with the secretary of state but not locally.

\section{Articles of Incorporation Recorded With Secretary of State But Not Recorded Locally}

There have been eighteen cases ${ }^{62}$ in which actions were brought to hold shareholders personally liable on the ground that the statutory requirement of recording the articles locally had not been fulfilled, although the purported articles of incorporation had been recorded in the office of the secretary of state. The results of these cases emphasizes the importance of the presence or absence of the fact that the dealings between plaintiff and the association were on a corporate basis. In

61. See text at notes 5,21 and 22 supra.

62. Gazette Pub. Co. v. Brady, 204 Ark. 396, 162 S.W.2d 494 (1942) ; Humphreys v. Mooney, 5 Colo. 282 (1880); Inter-Ocean Newspaper Co. v. Robertson, 296 Ill. 92, 129 N.E. 523 (1921) ; Hall v. Robertson, 213 I11. App. 147 (1919); Brown v. Melick, 185 Ill. App. 3 (1913); Hamill v. Watts, 180 Ill. App. 279 (1913) ; Curtis v. Meeker, 62 Ill. App. 49 (1895); Aetna Life Ins. Co. v. Weatherhogg, 103 Ind. App. 506, 4 N.E.2d 679 (1936) ; Newcomb-Endicott Co. v. Fee, 167 Mich. 574, 133 N.W. 540 (1911) ; Diamond Rubber Co. v. Fohey, 111 Miss. 654, 71 So. 906 (1916); Granby Co. v. Richards, 95 Mo. 106, 8 S.W. 246 (1888); Railroad Gazette v. Wherry, 58 Mo. App. 423 (1894) ; Swofford Co. v. Owen, 37 Okla. 616, 133 Pac. 193 (1913); Tonge v. Item Pub. Co., 244 Pa. 417, 91 Atl. 229 (1914); N.Y. Bank v. Crowell, 177 Pa. 313, 35 Atl. 613 (1896.); Guckert v. Hacke, 159 Pa. 303, 28 Atl. 249 (1893); Campbell v. Beaman, 68 Pa. Super. 30 (1917) ; Refsnes v. Myers, 164 Wash. 205, 2 P.2d 656 (1931). 
thirteen of the cases ${ }^{83}$ the plaintiff had understood that the association with which he was contracting was a corporation, and in all but two of these cases ${ }^{64}$ the shareholders were exonerated from personal liability. There were five cases ${ }^{65}$ in which the plaintiff had not dealt with the association on a corporate basis, and in each case he obtained a judgment against the shareholders personally; but the significance of this unanimity is somewhat diminished by the fact that four of the five cases emerged from a single state, namely, Pennsylvania.

Again the degree of the defendants' activity in the management of the enterprise proved unimportant. In the two cases ${ }^{66}$ of dealings on a corporate basis in which the defendants did not escape liability, they had not been active in the management. In the five cases where the dealings had not been on a corporate basis, in all of which judgment went against the defendants, they had been inactive associates in two, ${ }^{67}$ and participants in the management in the remaining three. ${ }^{\text {ws }}$

The reasoning to be found in these cases is as unsatisfactory as in those in the preceding sections. Almost invariably the opinions in favor of the defendants offer in justification the mere assertion that a "de facto" corporation has been formed, despite the failure to record the articles locally. In the cases in which the plaintiff's claim against the shareholders personally is upheld, the opinions do no more than aver that, until the articles are recorded locally, corporate existence does not begin, or that the shareholders are subject to the liability of partners. Such statements simply assume the answer to the issue in question, and do not provide a reason for the decision.

In the cases in the preceding section, where the articles had been recorded locally but not with the secretary of state, and the dealings were on a corporate basis, the plaintiffs prevailed almost half of the time. But in the cases in this section, where the articles had been recorded with the secretary of state but not locally and the dealings were on a corporate basis, the plaintiffs practically never succeeded in their efforts

63. Gazette Pub. Co. v. Brady, Humphreys v. Mooney, Inter-Ocean Newspaper Co. v. Robertson, Hall v. Robertson, Brown v. Melick, Curtiss v. Meeker, Aetna Life Ins. Co. v. Weatherhogg, Newcomb-Endicott Co. v. Fee, Diamond Rubber Co. v. Fohey, Granby Co. v. Richards, Railroad Gazette v. Wherry, Swofford Co. v. Owen, Refsnes v. Myers, all cited in note 62 supra.

64. Gazette Pub. Co. v. Brady, Hall v. Robertson, both cited in note 62 supra. In reality the Gazette Pub. Co. case stands alone, for the Supreme Court of Illinois, two years after the decision in Hall $v$. Robertson, decided in favor of the defendants in a similar suit involving the same association. See Inter-Ocean Newspaper Co. $v$. Robertson, supra note 62 .

65. Hamill y. Watts, Tonge v. Item Pub. Co., N.Y. Bank v. Crowell, Guckert v. Hacke, Campbell v. Beaman, all cited in note 62 supra.

66. See note 64 supra.

67. Tonge v. Item Pub. Co., and Campbell v. Beaman, both cited in note 62 supra.

68. Hamill v Watts, N.Y. Bank v. Crowell, Guckert v. Hacke, all cited in note 62 supra. 
to hold the shareholders personally responsible. Why do the decisions reflect this sharp distinction? To state that, when the articles have been recorded only with the secretary of state, a "de facto" corporation has been created is merely to reiterate with the aid of a Latin phrase the conclusion that the defendants are not personally liable. But why are they liable so much more frequently when the articles have been recorded only locally? Is it because the secretary of state is a more important official than the county clerk? Is it because the public is more likely to search in the secretary of state's office than in the county clerk's office for the status of the association? Is it because it is more important, for tax or other reasons, that the state rather than the county should be officially informed that the associates claim to be incorporated? Telling those who have recorded the articles only locally that they are not a "de facto" corporation provides no reason for or against their personal liability. If a patient tells his doctor that his (the patient's) hair is falling out in patches, and the doctor informs him that he is suffering from alopecia areata, the patient may get some comfort from having been told in Latin that his hair is falling out in patches. $^{69}$ But when a judge is officially asked to determine whether or not certain defendants are personally liable, it does not suffice for him merely to declare, with or without resort to Latin, that the defendants are or are not so liable. The parties and their attorneys and the legal profession are properly interested in the real reasoning upon which the judge arrived at his conclusion.

\section{Insufficient Capital Paid In}

Statutes in many states stipulate that a new incorporation shall receive a certain amount of capital before commencing to do business. This requirement may be expressed in terms of a fixed minimum number of dollars, e.g., $\$ 1000$, or in terms of a minimum percentage of the authorized capital stock; or the provision may be that stock subscriptions shall be fully paid in cash. The statutes referred to in the cases analyzed in this section do not expressly provide that limited liability of the associates shall be suspended during any period of non-compliance. A number of cases have arisen, however, in which creditors of the association have sought to charge the members or officers with personal liability, either because the statutory minimum of capital had not been furnished to the alleged corporation, or because, in the absence

69. If a patient reveals to his doctor that he is suffering from a case of sunburn, would it aid him to have the doctor diagnose his ailment as dermatitis calorica (inflammation of the skin produced by heat)? 
of a statutory requirement, the association had issued no shares and received no capital prior to incurring the obligation in question.

It might be contended that the cases in this section are not relevant to this article, because they relate to the internal organization of a corporation rather than to the steps in the process of incorporating, and hence are not related to the "de facto" doctrine. But if one conceives of the term "corporation" as a short-hand method of describing the presence of a number of legal attributes, including limited liability, then any inquiry into the combination of circumstances that will or will not result in this attribute is appropriate to an analysis of the "de facto" doctrine. In other words, the inquiry throughout this article has been not what are the facts that will produce that complex aggregate of legal relations called "corporation," but what are the facts that will produce freedom from personal liability (limited liability) among those who purport to have incorporated-and the presence or absence of sufficient capital appears to have an important bearing on this matter. Indeed, one might readily perceive a more direct connection between immunity from individual responsibility (limited liability) and the establishment of a substitute fund in the form of adequate association capital than between limited liability and recordation of the articles with the secretary of state. But the decisions do not sustain this idea.

Thirty-eight cases ${ }^{70}$ have been examined which present some problem concerning the individual responsibility of members of a chartered association for its obligations, based in whole or in part upon an alleged insufficiency in the paid-in capital of the association. In

70. Christian Co. v. Fruitdale Co., 121 Ala. 340, 25 So. 566 (1899) ; Williams Co. v. Quin, 44 Cal. App. 296, 186 Pac. 401 (1919); Ward-Truitt Co. v. Bryan \& Lamb, 144 Ga. 769, 87 S.E. 1037 (1916) ; Brooke v. Day, 129 Ga. 694, 59 S.E. 769 (1907) ; Burns v. Beck, 83 Ga. 471, 10 S.E. 121 (1889) ; Wright Co. v. Saul, 31 Ga. App. 129, 120 S.E. 23 (1923); Orr v. McLeay, 6 Ga. App. 417, 65 S.E. 164 (1909); Murdock v. Lamb, 92 Kan. 859, 142 Pac. 961 (1914); Central Nat. Bank v. Sheldon, 86 Kan. 460, 121 Pac. 340 (1912); Whetstone v. Crane Co., 1 Kan. App. 320, 41 Pac. 211 (1895) ; Provident Bank v. Saxon, 116 La. 408, 40 So. 778 (1906); Laflin Co. v. Sensheimer, 46 Md. 315 (1876) ; Salem Bank v. Almy, 117 Mass. 476 (1875) ; Love v. Ramsey, 139 Mich 47, 102 N.W. 279 (1905); Gow v. Collin, 109 Mich. 45, 66 N.W. 676 (1896); American Co. v. Bulkley, 107 Mich. 447, 65 N.W. 291 (1895); Moe v. Harris, 142 Minn. 442, 172 N.W. 494 (1919); Johnson v. Corser, 34 Minn. 355, 25 N.W. 799 (1886); Quinn v. Woods, 134 Miss. 621 , 99 So. 510 (1924) ; Natl. Bank v. Rockefeller, 195 Mo. 15, 93 S.W. 761 (1906); Webb v. Rockefeller, 195 Mo. 57, 93 S.W. 772 (1906); Journal Co. v. Nelson, 133 Mo. App. 482, 113 S.W. 690 (1908); Hyatt v. Van Riper, 105 Mo. App. 664, 78 S.W. 1043 (1904); Davidson v. Hobson, 59 Mo. App. 130 (1894); Bank v. Hall, 35 Ohio St. 158 (1878); Medill v. Collier, 16 Ohio St. 599 (1866) ; Beck v. Stimmel, 39 Ohio App. 510, 177 N.E. 920 (1931); Garwood v. Great Western Oil Co., 11 Ohio App. 96 (1919); Industrial B. \& L. Assoc. v. Williams, 131 Okla. 167, 268 Pac. 228 (1928); Rutherford v. Hill, 22 Ore. 218, 29 Pac. 546. (1892) ; McVicker v. Cone, 21 Ore. 353, 28 Pac. 76 (1891); Cochran v. Arnold, 58 Pa. 399 (1868) ; Paterson v. Arnold, 45 Pa. 410 (1863); Meyer v. Brunson, 104 S.C. 84, 88 S.E. 359 (1916) ; Crouch v. Gray, 154 Tenn. 521, 290 S.W. 391 (1926) ; Berwald v. Hamilton-Brown Shoe Co., 22 S.W.2d 760 (Tex. 1929); Berwald v. Tweedie Footwear Co., 22 S.W.2d 763 (Tex. 1929) ; American Co. v. Kinnear, 56 Wash. 210, 105 Pac. 630 (1909). 
thirty-three ${ }^{71}$ cases the dealings were on a corporate basis, and in twenty-two ${ }^{72}$ of these cases the associates were not subjected to individual liability. In short, the odds are here two to one in favor of the defendants, whereas their chances are only about fifty-fifty when the articles have not been recorded with the secretary of state. ${ }^{73}$

The factor of activity in the management of the association bulks somewhat larger here than in most of the other sections of this article. Inactive defendants were exonerated in nine cases ${ }^{74}$ and held liable in three ${ }^{75}$ (3-1), whereas the ratio with respect to defendants active in the management was thirteen ${ }^{76}$ to eight ${ }^{77}$ (almost 3-2).

In the remaining five cases ${ }^{78}$ the dealings were not on a corporate basis, and once again this seems to have been a most significant circumstance. Here, in marked contrast to the other thirty-three cases, ${ }^{79}$ the defendants were uniformly held to be personally liable for the plaintiff's claim, despite the fact that in four ${ }^{80}$ of the five cases the defendants had not been active in the management.

From these insufficient-capital cases there emerges a new factor not heretofore observed in this analysis of the incident of limited lia-

71. Williams Co. v. Quin, Ward-Truitt Co. v. Bryan \& Lamb, Burns v. Beck, Wright Co. v. Saul, Orr v. McLeay, Murdock v. Lamb, Central Nat. Bank v. Sheldon, Whetstone v. Crane Co., Provident Bank v. Saxon, Laflin Co. v. Sensheimer, Salem Bank v. Almy, Love v. Ramsey, Gow.v. Collin, American Co. v. Bulkley, Moe v. Harris, 142 Minn. 442, 172 N.W. 494 (1919); Johnson v. Corser, 34 Minn. 355, 25 Rockefeller, Journal Co. v. Nelson, Hyatt v. Van Riper, Davidson v. Hobson, Bank v. Hall, Garwood v. Great Western Oil Co., Industrial B. \& L. Assoc. v. Williams, Rutherford v. Hill, Cochran v. Arnold, Paterson v. Arnold, Meyer v. Brunson, Crouch v. Gray, Berwald v. Hamilton-Brown Shoe Co., Berwald v. Tweedie Footwear Co., American Co. v. Kinnear, all cited in note 70 supra.

72. Williams Co. v. Quin, Wright Co. v. Saul, Orr v. McLeay, Murdock v. Lamb, Laflin Co. v. Sensheimer, Salem Bank v. Almy, Love v. Ramsey, Gow v. Collin, American Co. v. Bulkley, Moe v. Harris, Quinn v. Woods, Natl. Bank v. Rockefeller, Webb. v. Rockefeller, Bank v. Hall, Garwood v. Great Western Oil Co., Industrial B. \& L. Assoc. v. Williams, Rutherford v. Hall, Cochran v. Arnold, Crouch v. Gray, Berwald v. Tweedie Footwear Co., 22 S.W.2d 763 (Tex. 1929); American Co. v.

73. See text at notes 51 and 52 supra.

74. Williams Co. v. Quin, Orr v. McLeay, Laflin v. Sensheimer, American Co. v. Bulkley, Quinn v. Woods, Webb v. Rockefeller, Bank v. Hall, Garwood v. Great Western Oil Co., Rutherford v. Hill, all cited in note 70 supra.

75. Provident Bank v. Saxon, Johnson v. Corser, Meyer v. Brunson, all cited in note 70 supra.

76. Wright Co. v. Saul, Murdock v. Lamb, Salem Bank v. Almy, Gow v. Collin, Love v. Ramsey, Moe v. Harris, Natl. Bank v. Rockefeller, Industrial B. \& L. Assoc. v. Williams, Cochran v. Arnold, Crouch v. Gray, Berwald v. Hamilton-Brown Shoe Co., Berwald v. Tweedie Footwear Corp., American Co. v. Kinnear, all cited in note 70 supra.

77. Burns v. Beck, Ward-Truitt Co. v. Bryan \& Lamb, Central Nat. Bank v. Sheldon, Whetstone v. Crane Co., Davidson v. Hobson, Hyatt v. Van Riper, Journal Co. v. Nelson, Paterson v. Arnold, all cited in note 70 supra.

78. Cliristian Co. v. Fruitdale Co., Brooke v. Day, Medill v. Collier, Beck v. Stimmel, McVicker v. Cone, all cited in note 70 supra.

79. See note 71 supra.

80. Brooke v. Day, Medill v. Collier, Beck v. Stimmel, McVicker v. Cone, all cited in note 70 sulpra. 
bility. If no stock subscriptions are obtained, no shares issued and no capital paid in, this fact situation is apparently regarded by the judiciary as a much stronger basis for imposing personal liability upon the defendant associates than if some shares have been issued and some capital paid in, even though this performance may be materially less than the statutory requirement. Of the thirty-eight insufficient-capital cases, sixteen ${ }^{81}$ involved situations in which the defendants had obtained a corporate charter and begun business in corporate form but without causing the corporation to be provided with any capital prior to incurring the obligation sued on by the plaintiff. In eleven ${ }^{82}$ of these sixteen cases personal liability was imposed upon the defendants, whereas in the other twenty-two cases ${ }^{83}$ in which some capital had been paid in, although allegedly an insufficient amount, liability was imposed upon the defendants in only five instances. ${ }^{84}$ In short, where no capital has been paid in, the odds are against the defendants more than two to one, but when some capital, though less than alleged to be required, has been paid in, the odds are in favor of defendants more than three to one.

But the reasoning in the opinions does not explain or even reflect this marked distinction between no capital and some capital. Where the defendants are found by the court to be personally liable, the reason frequently assigned, whether a no capital or a some capital situation, is that there was a "substantial" non-compliance with a statutory requirement, or that the corporation had no legal existence; no difference in degree is asserted, and yet it is a fact that in eleven ${ }^{85}$ of the sixteen cases $^{86}$ of personal liability, no capital had been paid in. Where the

81. Provident Bank v. Saxon, Johnson v. Corser, Williams Co. v. Quin, Rutherford v. Hill, Ward-Truitt Co. v. Bryan \& Lamb, Central Nat. Bank v. Sheldon, Whetstone v. Crane Co., Davidson v. Hobson, Hyatt v. Van Riper, Moe v. Harris, Natl. Bank v. Rockefeller, Industrial B. \& L. Assoc. v. Williams, Brooke v. Day, Beck v. Stimmel, McVicker v. Cone, Christian Co. v. Fruitdale Co., all cited in note 70 supra.

82. Provident Bank v. Saxon, Johnson v. Corser, Ward-Truitt Co. v. Bryan \& Lamb, Central Nat. Bank v. Sheldon, Whetstone v. Crane Co., Davidson v. Hobson, Hyatt v. Van Riper, Brooke v. Day, Beck v. Stimmel, McVicker v. Cone, Christian Co. v. Fruitdale Co., all cited in note 70 supra.

83. Burns v. Beck, Wright Co. v. Saul, Orr v. McLeay, Murdock v. Lamb, Laflin Co. v. Sensheimer, Salem Bank v. Almy, Love v. Ramsey, Gow v. Collin, American Co. v. Bulkley, Quinn v. Woods, Webb v. Rockefeller, Journal Co. v. Nelson, Bank v. Hall, Medill v. Collier, Garwood v. Great Western Oil Co., Cochran v. Arnold, Paterson v. Arnold, Meyer v. Brunson, Crouch v. Gray, Berwald v. Hamilton-Brown Shoe Co., Berwald v. Tweedie Footwear Co., American Co. v. Kinnear, all cited in note 70 supra.

84. Meyer v. Brunson, Burns v. Beck, Journal Co. v. Nelson, Paterson v. Arnold,

Medill v. Collier, all cited in note 70 supra.

85. See note 82 supra.

86. Christian Co. v. Fruitdale, Ward-Truitt Co. v. Bryan \& Lamb, Brooke v. Day, Burns v. Beck, Central Nat. Bank v. Sheldon, Whetstone v. Crane Co., Provident Bank v. Saxon, Johnson v. Corser, Journal Co. v. Nelson, Hyatt v. Van Riper, Davidson v. Hobson, Medill v. Collier, Beck v. Stimmel, McVicker v. Cone, Paterson v. Arnold, Meyer v. Brunson, all cited in note 70 supra. 
defendants are exonerated from personal liability, the courts proclaim, in both the no capital and the some capital cases, that a "de facto" corporation has been formed, or that there may be no collateral attack upon the defendants for their corporate shortcomings, or that the plaintiffs are estopped. But of the twenty-two non-liability cases ${ }^{87}$ only five ${ }^{88}$ involved a complete absence of capital paid in. There would appear to be a strong judicial aversion to permitting members of incorporated associations to claim freedom from personal liability before they have provided the association with any capital, but this aversion is not articulate in the opinions.

\section{SUMMARY}

In the foregoing five sections one hundred and twenty-four cases have been classified. Eighty-seven additional cases have been assembled in which various other types of defects in the incorporating process were involved and in which claims were asserted against the corporate associates personally because of such irregularities. But with respect to each of these miscellaneous defects, there are too few cases to enable one to draw any significant conclusions. For example, there are seven cases ${ }^{80}$ of unauthorized corporate purpose, fourteen cases ${ }^{90}$ involving various types of omitted publicity requirements, six cases ${ }^{01}$ in which the incorporation statute was allegedly unconstitutional, seven cases ${ }^{92}$

87. See note 72 supra.

88. Williams v. Quin, Rutherford v. Hill, Moe v. Harris, Natl. Bank v. Rockefeller, Industrial B. \& L. Assoc. v. Williams, all cited in note 70 sipra.

89. Staacke v. Routledge, 175 S.W. 444 (Tex. 1915), rev'd in part, 111 Tex. 489, 241 S.W. 994 (1922); Ivy Press v. McKechnie, 88 Wash. 643, 153 Pac. 1067 (1915); Mann v. Commonwealth Bond Corp., 27 F. Supp. 315 (S.D. N.Y. 1938) ; Merchants' \& Mfr's Bank v. Stone, 38 Mich. 779 (1878) ; Natl. Bank v. Texas Investment Co., 74 Tex. 421, 12 S.W. 101 (1889); Vredenburg v. Behan, 33 La. Ann. 627 (1881); Mandeville v. Courtright, 142 Fed. 97 (3d Cir. 1905).

90. Standard Varnish Co. v. Joy, 149 I1l. App. 25 (1909); Louisiana Bank v. Henderson, 116 La. 413, 40 So. 779 (1906); Williams v. Hewitt, 47 La. Ann. 1076, 17 So. 496 (1895). Bergeron v. Hobbs, 96 Wis. 641, 71 N.W. 1056 (1897) ; Henry v. Markesan State Bank, 68 F.2d 554 (Sth Cir. 1934); Hoyt v. McCallum, 102 Ill. App. 287 (1902); Sentell \& Co. v. Hewitt, 50 La. Ann. 3, 22 So. 970 (1898) ; Kleckner v. Turk, 45 Neb. 176, 63 N.W. 469 (1895); Hogue v. Capital Bank, 47 Neb. 929, 66 N.W. 1036 (1896); Cory v. Lee, 93 Ala. 468, 8 So. 694 (1891); Chieppo v. Chieppo, 88 Conn. 233, 90 Atl. 940 (1914); Kraemer v. Graf, 105 F.2d 117 (10th Cir. 1939) ; Clinton Co. v. Schwarz, 175 I11. App. 577 (1912) ; Pilsen Brewing Co. v. Wallace, 291 Ill. 59, 125 N.E. 714 (1919).

91. Planters' \& Miners' Bank v. Padgett, 69 Ga. 159 (1882) ; Jennings v. Dark, 175 Ind. 332, 92 N.E. 778 (1910); McClinch v. Sturgis, 72 Me. 288 (1881); Richards v. Minnesota Savings Bank, 75 Minn. 196, 77 N.W. 822 (1899); Eaton v. Walker, 76 Mich. 579, 43 N.W. 638 (1889); Chenango Bridge Co. v. Paige, 83 N.Y. 178 (1880).

92. Kaiser v. Lawrence Savings Bank, 56 Iowa 104, 8 N.W. 772 (1881) ; Snider's Sons' Co. v. Troy, 91 Ala. 224, 8 So. 658 (1890); Johnson v. Okerstrom, 70 Minn. 303, 73 N.W. 147 (1897); Stout v. Zulick, 48 N.J.L. 599, 7 Atl. 362 (1886); American Co. v. Heidenheimer, 80 'Tex. 344, 15 S.W. 1038 (1891); Shields v. Clifton Co., 94 Tenn. 123, 28 S.W. 668 (1894); Tennessee Co. v. Massey, 56 S.W. 35 (Tenn 1899). 


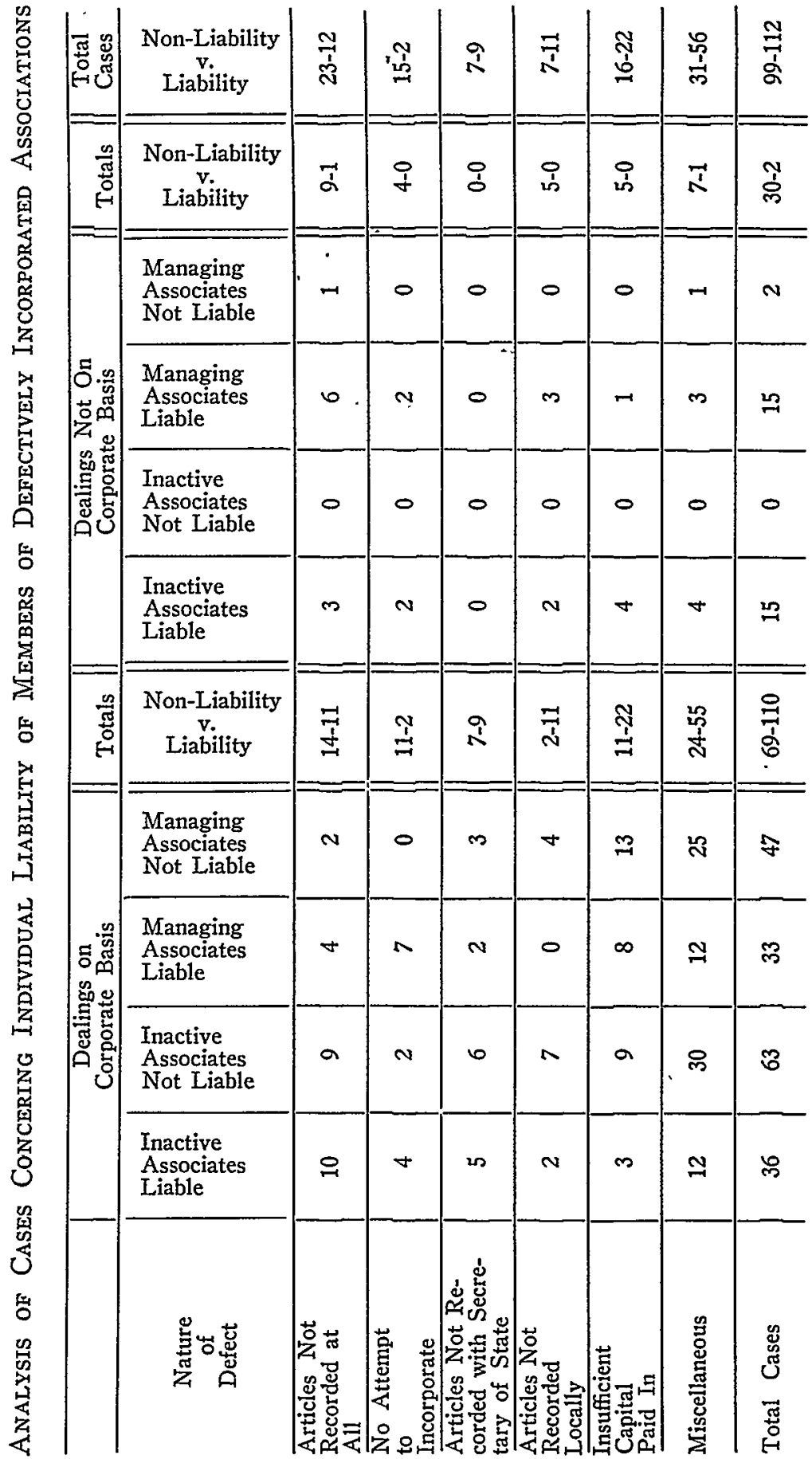


of defects in the execution of the articles, and so forth. To complete the picture these eighty-seven cases have been lumped under the heading "miscellaneous" and are included in the table on page 1174.

In recapitulation of the results of this entire body of two hundred and eleven cases, it appears that the factor of dealings on a corporate basis is of major importance. When the dealings were on a corporate basis, the defendants were held not to be personally liable in over sixty percent of the cases. But where there was no indication that the plaintiff negotiated with the association as a corporation, the members of the defective incorporation were denied limited liability in thirty out of thirty-two cases. Moreover, if the cases are examined as a whole, i.e., where the dealings were on a corporate basis, it develops that the managing associates fare to a minor degree discernably worse than those inactive in the management. The inactive associates prevailed almost sixty-four percent of the time, whereas the managing defendants won less than fifty-nine percent of their cases.

\section{CONCLUSTON}

When one endeavors to make a complete collection of the decided cases in a given field of law and painstakingly to analyze the opinions thus collected, he normally has a dual objective: first, to discover what the courts have actually been deciding in the area under survey (what facts have led to what legal consequences), and secondly, to ascertain why the courts have decided the cases the way they have. Such comprehensive studies and analyses are rather infrequent, perhaps because the twin endeavors can seldom, if ever, be satisfactorily realized. Let us first examine the "what."

The major difficulty in trying to extract from a mass of somewhat related cases an accurate formulation of what the courts have decided arises from the endless factual variations. Two or more cases are never identical; yet they may be similar, or at least analogous. But by what standard is similarity or analogy to be determined? In this article I have utilized three major bases of factual classification: (a) the type of defect in the incorporating process; $(b)$ whether or not the dealings between the plaintiff and the association were on a corporate basis; and (c) whether or not the defendants were active in the management of the association. But even the types of defect are not clear-cut in many of the cases; for example, sometimes a given case may involve more than one defect, and then one must either decide that one of the defects is dominant in the decision or create a separate category for this type of multiple defect. The decision as to whether a given transaction 
was on a corporate basis or not is even more arbitrary, for this factor frequently is not stressed in the opinion. Moreover, the classification of the defendants as active or inactive in management is often a matter of defendants as active or inactive in management is often a matter of considerable doubt, especially if they did not participate in the formation of the association or in the particular transaction sued upon.

Nevertheless, despite these difficulties, I developed certain principles of classification for the hybrid or maverick fact situations, and by endeavoring to group the cases with candor and consistency, I have arrived at a few conclusions as to what the courts have been deciding concerning the personal liability of members of defectively incorporated associations for obligations of their associations.

1. If the plaintiff did not accept the association as a corporation, as in the typical tort situation, or if the fact that the association claimed to be incorporated was unknown to him (i.e., if the dealings were not on a corporate basis), and if he elects to sue the members of the association individually instead of the association as such, he is virtually certain to succeed, in so far as the issue of their personal liability is concerned, if he can show almost any kind of a failure to comply with the statutory provisions for incorporation or with statutory conditions precedent to the commencement of business in corporate form. I base this conclusion on the fact that in thirty out of thirty-two cases in which the dealings were not on a corporate basis, the plaintiff prevailed although the cases involved a considerable variety of different types of defects. And yet the emphasis in the "de facto" doctrine, as traditionally expressed, is entirely upon the character of the defect ("colorable" attempt) and not at all upon the nature of the dealings between the parties.

2. If the articles of incorporation had not been recorded at all, either with the secretary of state or locally in the designated county office, prior to the transaction with the plaintiff, and if the dealings * with him were on a corporate basis, an action by the plaintiff to hold the members of the association personally liable to him has little more than an even chance of success. Recordation of the articles locally but not with the secretary of state produced only a minor variation in this outcome. These are startling results, for one might reasonably have assumed that failure to record the articles with the secretary of state, and especially failure to record at all, would be regarded by practically all judges as not constituting a "colorable" attempt to incorporate, and therefore as not extending to the defendants the immunity of the "de facto" doctrine. 
The cases referred to in the foregoing paragraph illustrate a significant analytical principle. If the defect in the effort to incorporate is of such a character as to justify the label "de facto corporation," the legal dogma is that the members of the association have the attribute of limited liability; but it is a legal and logical fallacy to conclude in the converse situation, i.e., when the defect induces the court to refrain from describing the association as a "de facto corporation," that the members are necessarily individually liable to an unlimited extent. A1though the factors sufficient for recognition of a "de facto corporation" may be absent, there may be other factors that provide the associates with legal protection from personal liability; ${ }^{93} e . g$., they may by contract limit their liability in relation to a specific person.

3. Where the plaintiff has dealt on a corporate basis with an association which, unbeknown to him, has made no attempt to incorporate, he is not precluded from suing the members of the association individually. In about half of the cases in which the plaintiff had dealt on a corporate basis with an association which had drafted articles of incorporation but had not recorded them with the secretary of state or at all, the defendant associates were held to be protected by the corporate nature of the dealings from personal liability. But where there have been no steps toward incorporation, the associates are afforded no such protection, and the fact that the transaction was on a corporate basis is not said to "estop" the plaintiff from pursuing the associates personally.

4. If the articles have been recorded with the secretary of state, although not recorded locally, and if the dealings were on a corporate basis, the associates are almost invariably accorded freedom from personal liability.

5. If the associates begin business in corporate form before obtaining any capital for the corporation, the courts are very likely to hold them personally liable for obligations of the association, even though the claimant dealt with the association on a corporate basis. But if the associates cause some capital to be paid in, though less than the required amount, those who dealt with them on a corporate basis have only a slim chance of imposing personal liability upon the associates.

93. Similarly, from the proposition that a contract is enforceable if supported by consideration, it does not follow logically that a promise is not enforceable if not supported by consideration. Although the presence of "consideration" is enough to render a promise enforceable, it may be that even in the absence of "consideration" other factors may induce courts to enforce promises. Of course, one might say that anything that induces courts to enforce a promise is "consideration," but so defined the term would have no definitive value. 
6. A summary of all the cases reveals that those active in the management of defectively incorporated associations have been subjected to personal liability to a somewhat greater extent than inactive shareholders. But when the cases involving any particular defect are separately examined, this factor does not stand out significantly, and one is not justified in concluding that participation in management is an important factor in predicting the probable impact of a defect in incorporation upon the liability of the members.

The foregoing analyses and conclusions indicate that the traditional doctrine of a "de facto" corporation is just so much jargon and ought to be abandoned. For those to whom this thought is repugnant two propositions might be culled from the decided cases: for the purpose of determining the presence or absence of the attribute of limited liability, (1) an association which has recorded articles of incorporation with the secretary of state is a "de facto" corporation, and the shareholders have limited liability if the dealings were on a corporate basis; and (2) an association which has made no attempt to incorporate is not a "de facto" corporation, and the associates are personally liable whether or not the dealings were on a corporate basis. With respect to other forms of defects or omissions in the incorporating process one cannot legitimately express any generalization in terms of the "de facto" doctrine, except possibly to state that for the purpose of determining the presence or absence of the attribute of limited liability, if the dealings were not on a corporate basis, an association which is in any respect defectively incorporated is not a "de facto" corporation, and the members are personally liable whether active in the management or not.

But even. in the formulation of these propositions nothing is gained or clarified by including the statement that the association "is a "de facto' corporation" or that it "is not a 'de facto' corporation." Omit these clauses and the propositions are just as meaningful. The assertion that the association is or that it is not a "de facto" corporation is not a reason for the result of limited or unlimited liability. Limited liability is only one of several corporate attributes, and apart from this incident one cannot safely predict whether, for some other purpose, the association will or will not be classified as a "de facto" corporation. Consequently, the statement in the foregoing propositions that the association is or is not a "de facto" corporation is literally nothing more than a somewhat obscure way of stating that the associates do or do not enjoy limited liability.

Moreover, the "de facto" statement, in addition to being pure surplusage, can be positively misleading. A case which states that, if the 
articles are recorded locally but not with the secretary of state, the associates are personally liable, is not likely to be cited for the proposition that such an association cannot acquire real property in the association name because this is so obviously a different issue. But if the first case states that the association in question is not a "de facto" corporation and "therefore" the associates are personally liable, those who do not concentrate on the purpose for which the association was judicially referred to as not a "de facto" corporation may be tempted subsequently to cite the case for the proposition that such a defectively incorporated association is not a "de facto" corporation and "therefore" it cannot acquire real property in its association name.

We come now to an inquiry into the "why" behind the decisions. Why do the courts almost invariably hold the associates personally liable if the dealings were not on a corporate basis, regardless of the nature of the defect? If the articles were recorded with the secretary of state but not locally, why do the courts with virtual unanimity exonerate the associates from personal liability if the dealings were on a corporate basis? If, on the other hand, the articles were recorded locally but not with the secretary of state, why do the courts almost half of the time impose personal liability on the associates even though the dealings were on a corporate basis?

Categorical answers to these questions cannot be extracted from the opinions. As indicated heretofore, if the decision is adverse to the defendants, the court is quite likely to assign as a reason that the association is not a "de facto" corporation; but, as observed above, this is not a reason but a mere reiteration of the ultimate judgment. If the decision is in favor of the defendants and the dealings were on a corporate basis, the court will frequently state that the plaintiff is "estopped" from imposing personal liability on the defendants. But why such plaintiffs are "estopped" when the articles have been recorded only with the secretary of state, and not when they have been recorded only locally, the opinions do not reveal.

One can ponder upon so-called policy considerations which, although not articulate in the opinions, may have been latent in the judicial mind. But such speculations do not appeal to me as particularly profitable. In arguing a particular case and commenting on prior decisions one may offer "good" reasons for or against certain judgments, even though these may not be the "real" reasons which induced the results. This, however, is largely a matter of personal opinion, unless there is a body of data from which substantiating support may be drawn. The fact remains that in the cases analyzed in this article the 
courts have rarely given either real reasons or good reasons, ${ }^{94}$ despite the emptiness of the "de facto" doctrine upon which they verbally rely. Fortunately, however, modern corporate legislation ${ }^{95}$ is rapidly minimizing the area of defective incorporation, ${ }^{96}$ and in time the doctrine of the "de facto" corporation may become merely an historic example of legal conceptualism at its worst.

94. This is not a matter peculiar to corporation law or the "de facto" doctrine, but is a common failing of the judiciary which a similarly critical examination of a body of cases in many another field of law will reveal. Many statements of legal conclusions which can be expressed in quite simple form are in reality complex utterances, if their complete implications are understood and intended. John Smith has possession of chattel X. John Smith has title to Blackacre. John Smith has entered into a common law marriage with Mary Jones. In order for such categorical statements to be accepted as accurate, i.e., free from doubt, there must be some normal sets of fact that persons learned in the law would agree are denoted by the concepts "possession," "title" and "marriage." But when we encounter variations from these "normal" fact situations, we discover that equally learned and competent lawmen differ as to whether or not the facts in question surely denote "possession" or "title" or "marriage," as the case may be. This confusion arises, as in the case of "de facto" corporation, from the circumstance that these apparently simple statements have as many possible ramifications as there are legal propositions expressed in terms of "possession," "title," "marriage," etc. To illustrate: To perfect a gift of a chattel, there must be a transfer of possession to the donee. To perfect an attachment or levy of execution, the sheriff must take possession of the chattel. To perfect a finding as to all but the rightful owner, the finder must take possession of the chattel. The unqualified assertion that "John Smith has possession of chattel X" in effect states that if the chattel was given to John Smith, the gift is effective; if John Smith was an attaching sheriff, he will prevail over subsequent competing sheriffs who attempt to levy on the same chattel; and if John Smith was a finder, his rights are superior to those of a later "finder" of the same chattel. If John Smith claims as a donee, what minimum physical relationship to chattel $\mathrm{X}$ must he establish if he is to prevail? If he seeks to prevail as an attaching sheriff, or if he claims as a finder, will he have to establish the same minimum factual relationship? The answers are to be found, as in the case of the "de facto" doctrine, only by examining and classifying the facts and the holdings of the pertinent cases. The opinions will tell us that some prevailed because they obtained "possession," and others did not prevail because they did not obtain "possession." But no one, including the judge, was certain that anyone had "possession" until after the decision was rendered! Wiil the judges recite the real or the good reasons for classifying certain sets of facts as "possession" and not others? They are no more likely to do so than in the case of the "de facto" corporation concept

I have sought very briefly to illustrate that the "for what purpose" approach to legal analysis is as applicable to the concept of "possession" as it is to the concept of "de facto" corporation. Any legal concept which is employed in more than one legal principle, such as "title," "marriage," "domicile," "authority," etc., manifestly requires a like analysis.

95. Certain pitfalls in the incorporating process have already been eliminated in many states, e.g., dual recordation of the articles is not required in twenty states. Fifteen states now provide that the issuance of a certificate of incorporation shall be conclusive evidence of due incorporation as to all persons except the state of incorporation. Many states no longer require a stated minimum of paid-in capital. Statutes expressly establishing the personal liability of designated persons for failure to comply with mandatory requirements are becoming more common.

96. This trend is illustrated by the fact that, of the post 1910 cases analyzed in this article, thirty-nine were decided between 1910 and 1919, thirty-four between 1920 and 1929, twenty-seven between 1930 and 1939, and only seven from 1940 to date. 